\title{
Coopetition in health care: A multi-level analysis of its individual and organizational determinants
}

Citation for published version (APA):

Westra, D., Angeli, F., Carree, M., \& Ruwaard, D. (2017). Coopetition in health care: A multi-level analysis of its individual and organizational determinants. Social Science \& Medicine, 186, 43-51. https://doi.org/10.1016/j.socscimed.2017.05.051

Document status and date:

Published: 01/08/2017

DOI:

10.1016/j.socscimed.2017.05.051

Document Version:

Publisher's PDF, also known as Version of record

Document license:

Taverne

Please check the document version of this publication:

- A submitted manuscript is the version of the article upon submission and before peer-review. There can be important differences between the submitted version and the official published version of record.

People interested in the research are advised to contact the author for the final version of the publication, or visit the DOI to the publisher's website.

- The final author version and the galley proof are versions of the publication after peer review.

- The final published version features the final layout of the paper including the volume, issue and page numbers.

Link to publication

\footnotetext{
General rights rights.

- You may freely distribute the URL identifying the publication in the public portal. please follow below link for the End User Agreement:

www.umlib.nl/taverne-license

Take down policy

If you believe that this document breaches copyright please contact us at:

repository@maastrichtuniversity.nl

providing details and we will investigate your claim.
}

Copyright and moral rights for the publications made accessible in the public portal are retained by the authors and/or other copyright owners and it is a condition of accessing publications that users recognise and abide by the legal requirements associated with these

- Users may download and print one copy of any publication from the public portal for the purpose of private study or research.

- You may not further distribute the material or use it for any profit-making activity or commercial gain

If the publication is distributed under the terms of Article $25 \mathrm{fa}$ of the Dutch Copyright Act, indicated by the "Taverne" license above, 


\title{
Coopetition in health care: A multi-level analysis of its individual and organizational determinants
}

\author{
Daan Westra ${ }^{\mathrm{a}, *}$, Federica Angeli ${ }^{\mathrm{a}, \mathrm{b}}$, Martin Carree ${ }^{\mathrm{c}}$, Dirk Ruwaard ${ }^{\mathrm{a}}$ \\ a Department of Health Services Research, CAPHRI Care and Public Health Research Institute, Faculty of Health, Medicine and Life Sciences, Maastricht \\ University, Duboisdomein 30, 6229 GT Maastricht, The Netherlands \\ ${ }^{\mathrm{b}}$ Department of Organization Studies, School of Social and Behavioural Sciences, Tilburg University, Warandelaan 2, 5038 AB Tilburg, The Netherlands \\ ${ }^{c}$ Department of Organisation and Strategy, School of Business and Economics, Maastricht University, Tongersestraat 53, 6211 LM, Maastricht, The \\ Netherlands
}

\section{A R T I C L E I N F O}

\section{Article history:}

Received 16 December 2016

Received in revised form

18 May 2017

Accepted 25 May 2017

Available online 26 May 2017

\section{Keywords:}

Coopetition

Inter-organizational cooperation

Managed competition

Human resources

The Netherlands

\begin{abstract}
A B S T R A C $T$
Cooperative inter-organizational relations are salient to healthcare delivery. However, they do not match with the pro-competitive healthcare reforms implemented in several countries. Healthcare organizations thus need to balance competition and cooperation in a situation of 'coopetition'. In this paper we study the individual and organizational determinants of coopetition versus those of cooperation in the pricecompetitive specialized care sector of the Netherlands. We use shared medical specialists as a proxy of collaboration between healthcare organizations. Based on a sample of 15,431 medical specialists and 371 specialized care organizations from March 2016, one logistic multi-level model is used to predict medical specialists' likelihood to be shared and another to predict their likelihood to be shared to a competitor. We find that different organizations share different specialists to competitors and non-competitors. Cooperation and coopetition are hence distinct organizational strategies in health care. Cooperation manifests through spin-off formation. Coopetition occurs most among organizations in the pricecompetitive market segment but in alternative geographical markets. Hence, coopetition in health care does not appear to be particularly anti-competitive. However, healthcare organizations seem reluctant to share their most specialized human resources, limiting the knowledge-sharing effects of this type of relation. Therefore, it remains unclear whether coopetition in health care is beneficial to patients.
\end{abstract}

(c) 2017 Elsevier Ltd. All rights reserved.

\section{Introduction}

Health care is a service which is typically delivered to patients by several providers (i.e. organizations) cooperating in interorganizational networks (Goes and Park, 1997; Luke et al., 1989; Provan et al., 2011). This is the result of the high level of specialization of providers and the fragmented nature of the sector due to its funding schemes (Gittell and Weiss, 2004; Provan and Sebastian, 1998). Inter-organizational networks can consist of various types of temporary or long-lasting inter-organizational relations through which resources are transferred between organizations, underpinned by various organizational motives (Oliver, 1990; Van de Ven,

\footnotetext{
* Corresponding author.

E-mail addresses: d.westra@maastrichtuniversity.nl (D. Westra), federica. angeli@maastrichtuniversity.nl, f.angeli@tilburguniversity.edu (F. Angeli), m. carree@maastrichtuniversity.nl (M. Carree), d.ruwaard@maastrichtuniversity.n (D. Ruwaard).
}

1976). Examples of inter-organizational relations in health care include patient transfers, consortia, shared human resources, and interlocking directorates (e.g. Fottler et al., 1982; Westra et al., 2017). Well-structured cooperative inter-organizational healthcare networks are considered an efficient resource allocation method and have proven beneficial for quality of care (e.g. Lomi et al., 2014; Provan and Milward, 1995).

The absence of (price-)competition has long been considered a salient factor for inter-organizational cooperation to flourish (Jarillo, 1988) and much of the initial research regarding interorganizational cooperation was consequently conducted in industries like health care (e.g. Levine and White, 1961). However, several Western countries have passed market-based reforms in an attempt to contain healthcare costs (Cutler, 2002; Maarse et al., 2016). Such reforms, aim to stimulate competition between providers which should in turn optimize value in the industry (Enthoven, 1993; Westra et al., 2017), with value being the best health outcomes per dollar spent (Porter, 2010). The introduction of 
competition effectively renders many cooperating healthcare providers in a situation where they simultaneously cooperate and compete, two diametrically opposed logics (Bengtsson and Kock, 2000).

During the past two decades, simultaneous cooperation and competition between organizations has become an increasingly established phenomenon in strategic management literature known as coopetition (Brandenburger and Nalebuff, 1996). It has attracted particular attention in knowledge-intensive industries (Bengtsson and Kock, 2014; Bouncken et al., 2015). While some have dubbed coopetition 'sleeping with the enemy' (Quint, 1997), the concept is primarily based on 'growth commensalism' (Ingram and Yue, 2008). It is described as a phenomenon in which competitors cooperate to create or expand a market but compete to appropriate the largest possible share of that market in academic literature (e.g. Ritala and Hurmelinna-Laukkanen, 2009). Along this line, knowledge sharing and inter-organizational learning are considered the primary motives to cooperate with competitors (e.g. Ritala and Hurmelinna-Laukkanen, 2009). Improved competitiveness and innovativeness resulting from scale advantages are considered the main outcomes of this process (e.g. Gnyawali and Park, 2011) when the tensions inherent to the opposite logics of competition and cooperation are well-managed at individual and organizational level (e.g. Das and Teng, 2000). Coopetition is primarily studied at the inter-organizational level using case studies (Bouncken et al., 2015) and empirical work has mostly failed to capture the multi-level nature of the phenomenon (Bengtsson and Kock, 2014).

In health care, coopetition has been described as 'the new market milieu' (Gee, 2000). Yet, despite the implementation of competition in several healthcare systems, and the inherent tensions this brings cooperating competitors, coopetition has not been studied extensively in the sector. In their systematic review of the coopetition literature, Bouncken et al. (2015) identified only two studies which explicitly utilize the concept of coopetition in health care (i.e. Barretta, 2008; Peng and Bourne, 2009). Albeit perhaps not explicitly referencing coopetition, simultaneous competition and cooperation has not gone unnoticed by health services researchers. Studies by Lomi and Pallotti (2012), Mascia et al. (2012), and Mascia et al. (2016) for example show that competing hospitals in the Italian National Health System (NHS) are more likely to collaborate with one another. Mascia and Di Vincenzo (2011) find that while cooperation benefits hospitals' performance, competition hampers it. Conversely, Plochg et al. (2006) find that marketbased reforms hamper cooperation between providers in the Netherlands.

Most of the empirical research regarding coopetition in health care stems from the Italian NHS in which price-competition is absent (Mascia et al., 2012) and has focused on transferring patients, a temporary relation between organizations (Mascia et al., 2012). Empirically, long-lasting resource flows between organizations have only been considered to a limited extent in this stream of literature. Furthermore, the coopetition literature in health care has either operationalized competition as a relational phenomenon at the dyadic level (e.g. Mascia and di Vincenzo, 2013) or at the industry level as an industry characteristic (e.g. Plochg et al., 2006). Conceptualizations of competition at the sub-industry level (Ingram and Yue, 2008), which have been applied in healthcare management research (e.g. Marlin et al., 2002), have not been juxtaposed with cooperation. Strategic groups are arguably the most well-known sub-industry conceptualization of competition. Strategic groups refer to groups of organizations within an industry which offer similar products or services and which can thus be considered each other's main competitors (e.g. McGee and Thomas, 1986).
We aim to advance our understanding of coopetition in health care, and thus of competitive healthcare markets using the following research question; 'What are the individual and organizational determinants of coopetition versus those of cooperation in health care?'. Consequently, we study the determinants of coopetition (i.e. simultaneous cooperation and competition) and contrast these with the determinants of cooperation. This enables us to unravel the similarities and differences between cooperation and coopetition in a price-competitive healthcare market. Furthermore, we answer the call for a multi-level approach to studying coopetition by examining which resources are shared by which organizations. Lastly, we study a long-lasting relation specific to the healthcare sector, namely shared human resources (i.e. medical specialists). Medical specialists are a key resource of hospitals (Robinson and Luft, 1985), yet it is common for them to be affiliated to multiple hospitals simultaneously (Gee, 2000; Zuckerman et al., 1995). This approach draws from the labor mobility literature in which employee inflows are perceived as vehicles to attract tacit knowledge of an employee's former employer and as conduits of communication between current and former employers (e.g. Corredoira and Rosenkopf, 2010; Madsen et al., 2003). It also captures the tension inherent to simultaneous cooperation and competition since shared medical specialists between healthcare organizations has been described as anti-competitive (Enthoven, 1988).

\section{Methods}

\subsection{Setting}

We study coopetition in the specialized care market of the Netherlands. Price-competition was introduced in this sector by the Health Insurance Act (HIA) in 2006 as a consequence of selective contracting of providers by third-party purchasers (i.e. insurers) (Enthoven and van de Ven, 2007). Upon introduction of the HIA in 2006 , it was limited to approximately $7 \%$ of the specialized care services but since 2012, price-competition pertains to roughly $70 \%$ of the specialized care services (Schut and Varkevisser, 2017). In 2013, more than half of the curative healthcare expenditure under the HIA was spent on specialized care services which are delivered by academic hospitals, teaching hospitals, general hospitals, specialized hospitals, and independent treatment centers (Nza, 2015; Vektis, 2015).

\subsection{Data}

Our study, which was not subjected to the Dutch 'Research involving Human Subjects act' following the decision of the Maastricht University Medical Center ethics committee (number 14-5-028), was based on data owned by Vektis, the Dutch center for information and standardization in health care. Specifically, we used the publically available 'Algemeen Gegevensbeheer Code' (AGBcode) data (version U145, released in the second half of March 2016) which is designed to handle claims and to analyze healthcare consumption (de Rouw, 2016). An AGB-code is a unique identifier for healthcare professionals and healthcare organizations in the Netherlands. Insurers only reimburse claims with a valid combination of a professional's and organization's AGB-code (de Rouw, 2016). In order to receive an AGB-code, medical specialists need to be listed in the country's medical (BIG) registry and specialized care organizations need to possess a unique chamber of commerce number and governmental admission to the market (de Rouw, 2016). The AGB-code database contains the active affiliations of professionals to healthcare organizations as well as a professional's and an organization's basic characteristics (e.g. age, gender, 
experience, type of organization, and location). AGB-code data has previously been used to explore the occurrence of shared specialists in the Netherlands (Westra et al., 2016).

\subsection{Sample}

From the database we selected all medical specialists ( $n=19,852)$, all specialized care organizations ( $n=969)$, and all active affiliations of the specialists to the organizations ( $n=26,614)$. Because the financial incentive for specialists to keep the database up to date (Smeets et al., 2011) becomes obsolete upon their retirement, all specialists who had reached the Dutch retirement age on April 1st, 2016 were excluded. Five specialist who were below the age of 30 on April 1st, 2016 were also excluded, since only professionals who have completed their residencies are eligible for an AGB code, which is practically impossible before the age of 30 in the Netherlands (van der Velden and Hingstman, 2003). Specialists without an active affiliation to any of the organizations in our sample were disregarded.

Specialized hospitals, including psychiatric hospitals, were excluded because they can also be categorized as long-term care organizations in the AGB-code data and different entry barriers can apply (de Rouw, 2016). Our sample hence included independent treatment centers (ITCs), general hospitals, teaching hospitals, and academic hospitals. Similar to what Gaynor and Town (2012) describe as ambulatory surgical centers, ITCs are ambulatory clinics that typically offer low-complex outpatient care in a few specialties. Furthermore, the distinction between general, teaching, and academic hospitals is similar to what Zwanziger et al. (1994) describe as primary, secondary, and tertiary hospital services. General hospitals offer basic (i.e. 'primary') hospital services in several specialties. Teaching hospitals offer services which require more specialized resources (i.e. 'secondary services') and are hospitals where medical students and residents can be placed. Academic hospitals offer highly specialized (i.e. 'tertiary') services on a regional basis and are responsible for the training of medical students and residents in close collaboration with a university (Nza, 2014; Zwanziger et al., 1994). Because the services offered by organizations within each of these categories are distinct and most closely resemble the services offered by organizations in the same category, each organizational type was considered a separate strategic group.

All specialists were assigned an organization to which they were primarily affiliated and, if applicable, an organization to which they were shared. We calculated the duration of each active affiliation a specialist had using the starting date of the affiliation. The organization to which a specialist had the longest active affiliation was considered the specialist's primary organization. The second organization to which a specialist was affiliated was considered the organization to which a specialist was shared. Specialists with more than two affiliations were considered shared to the strongest competitor. That is, the most geographically proximate organization in the same strategic group. In cases none of the additional affiliations were to an organization in the same strategic group we considered them shared to the organization to which they had the second-longest affiliation. Specialists with equal affiliation durations for their first two affiliations were disregarded because we were unable to determine the primary organization which decided to share the specialist in these cases. Ultimately, we retained a sample of 15,431 medical specialists in 29 medical specialties (see Appendix 1), primarily affiliated to 371 specialized care organizations.

\subsection{Measures and model specification}

\subsubsection{Dependent variables}

In the Netherlands, medical specialists are either employed by a hospital or independent, self-employed, entrepreneurs organized in per-specialty partnerships called 'maatschap' (Varkevisser et al., 2008). Sharing a medical specialist thus either implies that an organization shares a tenured employee or that a 'maatschap' is affiliated to multiple organizations. In both cases the hospital board is responsible for its specialists (Scholten and Van der Grinten, 2005) and decides whether or not to share a specialist (Westra et al., 2016). Previous research has identified sharing specialists as an emergent, yet deliberate, strategy of healthcare organizations given the formal decision-making authority and the strategic considerations underpinning the decision (Westra et al., 2016).

We used two dependent variables, both of which indicated whether a specialist was shared between two organizations in our sample. Our first was a binary indicator coded 1 when a specialist was shared to another organization in our sample and 0 otherwise. Based on this first dependent variable, we modeled the individual and organizational determinants of cooperation. That is, a specialist's general likelihood to be shared. Our second dependent variable was a binary indicator coded 1 when specialists who were shared, as identified by our first independent variable, were shared to an organization in the same strategic group as their primary organization and 0 otherwise. Based on this second dependent variable we modeled the individual and organizational determinants of coopetition. That is, a specialist's likelihood to be shared to a competitor (i.e. an organization in the same strategic group).

\subsubsection{Model specification}

We constructed a multilevel logistic regression model with maximum likelihood estimation, Laplace likelihood approximation, and logit link function for both dependent variables using the 'glimmix' procedure in the SAS software for Microsoft Windows version 9.3. The multilevel structure was used in order to account for the separation of effects at the individual and organizational level (Snijders and Bosker, 2012). Formally we specified the following model:

$$
\begin{aligned}
& \operatorname{Logit}\left(\pi_{i j}\right) \\
& =\alpha_{j}+\beta 0_{i j}+\beta 1 \cdot \text { Gender }_{i}+\beta 2 \cdot \text { PhD }_{i}+\beta 3 \cdot \text { Experience }_{i} \\
& +\beta 4 \cdot \text { Affiliation Duration }_{i j}+\beta 5 \cdot \text { Independent }_{i j}+\sum_{k=6}^{34} \beta k \cdot \text { Specialty }_{i j k} \\
& +\beta 35 \cdot \text { Traveltime }_{i j}+\beta 36 \cdot \text { Traveltime }_{i j}^{2}+\gamma 1 \cdot \text { Size }_{j} \\
& +\gamma 2 \cdot \text { Competition }_{j}+\gamma 3 \cdot \text { MHGmembership }_{j}+\gamma 4 \cdot \text { ITC }_{j} \\
& +\gamma 5 \cdot \text { GeneralHospital }_{j}+\gamma 6 \cdot \text { Teaching Hospital }_{j} \\
& +\gamma 7 \cdot \text { Academic Hospital }_{j}+\varepsilon_{i j}
\end{aligned}
$$

where: $\alpha_{j}=\alpha+\mu_{j}$

\subsubsection{Level-1 independent variables}

$\beta 0_{\mathrm{ij}}$ through $\beta 37_{\mathrm{ij}}$ represent personal characteristics of medical specialists and serve as first-level predictors of the likelihood that a specialist is shared. $\beta 0_{\mathrm{ij}}$ represents the first-level intercept. Gender, experience, and the specialty of a specialist are all common personal-level variables in research regarding collaboration in health care (e.g. Landon et al., 2012). Gender ${ }_{i}$ was coded 1 for male and 0 for female. Experience ${ }_{i}$ was operationalized as the number of 
years between April 1st, 2016 and the date on which a specialist finished his or her residency. $\sum_{k=6}^{34} \beta k \cdot$ Specialty $_{i j k}$ represents 29 mutually exclusive dummies indicating a specialist's medical specialty coded 1 for yes and 0 for no. Internal medicine, the largest specialty in our sample, serves as the reference category. $\mathrm{PhD}_{\mathrm{i}}$ indicates whether the specialist holds a $\mathrm{PhD}$ (i.e. 1 for yes and 0 for no) and is used as an indication of seniority (Mascia et al., 2015) in medical terms. Affiliation Duration ${ }_{\mathrm{ij}}$ represents how long a specialist has been affiliated to their primary organization measured in years per April 1st, 2016 and is a predictor of employee turnover in labor economics (e.g. Lane and Parkin, 1998). Independent $\mathrm{ij}_{\mathrm{j}}$ is a dummy variable coded 1 for specialists who work in a 'maatschap' and 0 for employed specialists. Traveltime ${ }_{\mathrm{ij}}$ and Traveltime ${ }_{1}^{2}$, are only used in model 2 and indicate the (curvilinear) effect of geographical proximity, operationalized as travel time in hours, between a specialist's primary and secondary organization. The travel time between each dyad of organizations was retrieved from the Google Maps API through inputting both organizations' visiting address using the SAS software for Microsoft Windows version 9.3. Our findings proved robust against operationalizing proximity as geographical distance like in previous research (Landon et al., 2012; Mascia et al., 2015).

\subsubsection{Level-2 independent variables}

$\alpha_{j}$ denotes the second level random intercept specified as the grand mean $\alpha$ and hospital specific deviation from that mean $\mu_{\mathrm{j} .} \gamma 1_{j}$ through $\gamma 7_{j}$ represent organizational characteristics of a specialist's primary organization and serve as second-level predictors of the likelihood to be shared. Size $e_{j}$ constitutes a common variable in studies regarding hospital strategies and was operationalized as the total number of specialists affiliated to the organization expressed

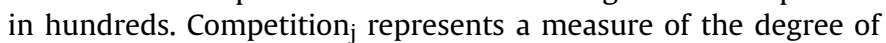
competition to which an organization is exposed. It is operationalized as the cumulative degree of service-overlap of organization $j$ with all other organizations $k$ in a $10 \mathrm{~km}$ radius. The degree of service overlap between organization $j$ and another organization $k$ was defined as the percentage of specialties offered by organization $j$ which organization $k$ also offers. We considered an organization to offer a specialty when at least one specialist of a specialty was primarily affiliated to the organization. The $10 \mathrm{~km}$ radius represents the local nature of specialized care markets (Sohn, 2002) but findings proved robust against higher radiuses. MHS membership is a dummy variable coded 1 when an organization is part of a multihospital system (MHS) (Dranove and Shanley, 1995) in which at least one other organizations from our sample is also a member and 0 otherwise. The variable was constructed based on the group ID associated with each AGB-code in the Dutch national company registry of Statistics Netherlands. ITC $_{\mathrm{j}}$, General Hospital $\mathrm{j}_{\mathrm{j}}$, Teaching Hospital $_{\mathrm{j}}$, and Academic Hospital ${ }_{\mathrm{j}}$ are mutually exclusive dummies indicating the type (i.e. strategic group) of each organization. General hospitals serve as the reference category. Lastly, $\varepsilon_{i j}$ indicates the error term.

\section{Results}

\subsection{Descriptive statistics}

Table 1 presents the descriptive statistics of the first-level variables. It reveals that roughly $28 \%$ of all medical specialists in our sample $(n=15,431)$ are shared and that $31 \%$ of those shared specialists $(n=4277)$ are shared to an organization in the same strategic group. Of the 15,431 specialists, $61 \%$ are male, $52 \%$ are employed by their primary organization, and $22 \%$ have obtained a $\mathrm{PhD}$. Of the 4277 shared specialists $66 \%$ is male, $45 \%$ is employed by their primary organization and $20 \%$ has a PhD. On average, specialists have almost 12 years of experience and have been affiliated to their primary organization for roughly 9.5 years. Shared specialists are, on average, more experienced (i.e. 13 years) and have longer affiliations to their primary organization (i.e. 10.5 years). Most of the specialists, as well as the shared specialists, are primarily affiliated to a general or a teaching hospital. Lastly, on average, shared specialists are shared to organizations located almost an hour away from their primary organization.

Table 2 displays the descriptive statistics of the characteristics of healthcare organizations. It indicates that 371 organizations served as the primary organization of one or more specialists in our sample. On average, 56 specialists were affiliated to an organization and organizations were exposed to 5.74 organizations in a $10 \mathrm{~km}$ radius with which they had full service overlap. Most organizations in our sample are ITCs (78\%), followed by general hospitals (13\%), teaching hospitals (8\%), and academic hospitals (2\%). Of those 371 organizations, 226 organizations cooperate. That is, they served as the primary organization of at least one shared specialist. On average, 90 specialists are affiliated to these organizations and they have 5.15 organizations in a $10 \mathrm{~km}$ radius with which they have complete service overlap. Most of the organizations to which shared specialists are primarily affiliated are ITCs (63\%), followed by general hospitals (21\%), teaching hospitals (13\%), and academic hospitals (4\%). Of these 226 organizations, 176 engage in coopetition. That is, they share at least one specialist to an organization in the same strategic group.

Table 3 indicates the number of specialists shared between each type of organization at organizational level. The rows represent the type of organization to which specialists are primarily affiliated and

Table 1

Individual-level descriptive statistics.

\begin{tabular}{|c|c|c|c|c|c|c|c|c|c|c|}
\hline & \multicolumn{5}{|l|}{ Model 1} & \multicolumn{5}{|c|}{ Model 2} \\
\hline & $\mathrm{n}$ & Mean & SD & Min & Max & $\mathrm{n}$ & Mean & SD & Min & Max \\
\hline Specialists shared & 15,431 & $27.72 \%$ & & 0 & 1 & & & & & \\
\hline Specialists shared within strategic group & & & & & & 4277 & $30.98 \%$ & & 0 & 1 \\
\hline Gender & 15,431 & $61.25 \%$ & & 0 & 1 & 4277 & $66.03 \%$ & & 0 & 1 \\
\hline $\mathrm{PhD}$ & 15,431 & $21.53 \%$ & & 0 & 1 & 4277 & $20.22 \%$ & & 0 & 1 \\
\hline Experience of specialist & 15,130 & 11.86 & 7.73 & 0 & 36 & 4198 & 12.90 & 7.65 & 0 & 36 \\
\hline Affiliation duration & 15,426 & 9.44 & 7.12 & 0 & 36 & 4277 & 10.50 & 7.08 & 0 & 36 \\
\hline Independent & 15,431 & $47.77 \%$ & & 0 & 1 & 4277 & $55.18 \%$ & & 0 & 1 \\
\hline Medical specialty & \multicolumn{5}{|c|}{ See Appendix 1} & \multicolumn{5}{|c|}{ See Appendix 1} \\
\hline Travel time to secondary organization & & & & & & 4277 & 0.92 & 0.59 & 0 & 3.20 \\
\hline Primarily affiliated to an ITC & 15,431 & $5.17 \%$ & & 0 & 1 & 4277 & $8.39 \%$ & & 0 & 1 \\
\hline Primarily affiliated to a general hospital & 15,431 & $34.82 \%$ & & 0 & 1 & 4277 & $41.17 \%$ & & 0 & 1 \\
\hline Primarily affiliated to a teaching hospital & 15,431 & $36.85 \%$ & & 0 & 1 & 4277 & $37.74 \%$ & & 0 & 1 \\
\hline Primarily affiliated to an academic hospital & 15,431 & $23.15 \%$ & & 0 & 1 & 4277 & $12.70 \%$ & & 0 & 1 \\
\hline
\end{tabular}


Table 2

Organizational-level descriptive statistics.

\begin{tabular}{|c|c|c|c|c|c|c|c|c|c|c|}
\hline & \multicolumn{5}{|c|}{ Model 1} & \multicolumn{5}{|c|}{ Model 2} \\
\hline & $\mathrm{n}$ & Mean & SD & Min & Max & $\mathrm{n}$ & Mean & SD & Min & Max \\
\hline Size & 371 & 0.56 & 1.14 & 0.01 & 7.07 & 226 & 0.90 & 1.35 & 0.01 & 7.07 \\
\hline Cooperate & 371 & $60.92 \%$ & & 0 & 1 & 226 & $100 \%$ & & 0 & 1 \\
\hline Engage in coopetition & & & & & & 226 & $77.88 \%$ & & 0 & 1 \\
\hline Competition & 371 & 5.74 & 6.90 & 0.67 & 81.11 & 226 & 5.15 & 6.98 & 0.95 & 81.11 \\
\hline MHS membership & 371 & $22.91 \%$ & & 0 & 1 & 226 & $30.97 \%$ & & 0 & 1 \\
\hline Academic hospital & 371 & $2.16 \%$ & & 0 & 1 & 226 & $3.54 \%$ & & 0 & 1 \\
\hline ITC & 371 & $77.63 \%$ & & 0 & 1 & 226 & $63.27 \%$ & & 0 & 1 \\
\hline Teaching hospital & 371 & $7.55 \%$ & & 0 & 1 & 226 & $12.39 \%$ & & 0 & 1 \\
\hline General hospital & 371 & $12.67 \%$ & & 0 & 1 & 226 & $20.80 \%$ & & 0 & 1 \\
\hline
\end{tabular}

Table 3

Number of shared specialists between types of organizations. The diagonal represents the number of specialists shared within the strategic group.

\begin{tabular}{|c|c|c|c|c|c|c|c|}
\hline \multirow[t]{2}{*}{ Shared by } & \multicolumn{4}{|c|}{ Shared to } & \multirow{2}{*}{$\begin{array}{l}\text { Number of specialists } \\
\text { shared }\end{array}$} & \multirow{2}{*}{$\begin{array}{l}\text { Number of specialists primarily affiliated to } \\
\text { organizational type }^{a}\end{array}$} & \multirow{2}{*}{$\begin{array}{l}\% \text { of specialist shared per } \\
\text { organizational type }\end{array}$} \\
\hline & ITC & $\begin{array}{l}\text { General } \\
\text { hospital }\end{array}$ & $\begin{array}{l}\text { Teaching } \\
\text { hospital }\end{array}$ & $\begin{array}{l}\text { Academic } \\
\text { hospital }\end{array}$ & & & \\
\hline ITC & 158 & 75 & 120 & 6 & 359 & 798 & $44.99 \%$ \\
\hline $\begin{array}{l}\text { General } \\
\text { hospital }\end{array}$ & 661 & 574 & 423 & 103 & 1761 & 5373 & $32.77 \%$ \\
\hline $\begin{array}{l}\text { Teaching } \\
\text { hospital }\end{array}$ & 451 & 579 & 500 & 84 & 1614 & 5687 & $28.38 \%$ \\
\hline $\begin{array}{l}\text { Academic } \\
\text { hospital }\end{array}$ & 81 & 191 & 178 & 93 & 543 & 3573 & $15.20 \%$ \\
\hline Total & 1351 & 1419 & 1221 & 286 & 4277 & 15,431 & \\
\hline
\end{tabular}

a The total number of affiliated specialists to each type of organization was calculated based on the percentage of specialists affiliated to each type reported in Table 1 .

the columns represent the type of organization to which specialists are shared. The diagonal represents the number of specialists shared to organizations in the same strategic group (i.e. $31 \%$, or 1325 of the 4277). Almost half of the specialists shared by an ITC are shared to another ITC (i.e.158 of the 359). Approximately a third of the specialists who are shared by a general hospital or a teaching hospital are shared to another general hospital or teaching hospital (574 out of 1761 and 500 out of 1614 respectively), while roughly a fifth of the specialists shared by an academic hospital are shared to another academic hospital (i.e. 93 out of 543). Table 3 furthermore highlights that $45 \%$ of the specialists who are primarily affiliated to an ITC, $33 \%$ of all specialists primarily affiliated to a general hospital, $28 \%$ of all specialists primarily affiliated to a teaching hospital, and $15 \%$ of all specialists primarily affiliated to an academic hospital are shared.

Table 4 presents the results of our logistic multilevel regression models predicting the likelihood a specialist is shared and the likelihood a specialist is shared within a strategic group. Only the results of the full model are presented. In both cases the full model, including all individual and organizational level predictors, displayed the best model fit, indicated by the Akaike Information Criterion. The intraclass correlation (ICC), calculated following the method described by Snijders and Bosker (2012), reveals that a specialist's primary organization explains roughly a quarter of the variance in the likelihood to be shared (i.e. model 1) and more than a third of the variance in the likelihood to be shared to a competitor.

\subsection{Likelihood of cooperation}

Model 1 in Table 4 reveals the results of the regression model predicting the likelihood that a specialist is shared (i.e. the likelihood of cooperation). The results indicate that male specialists are $25 \%$ more likely to be shared than female specialists. Furthermore, a specialist is 3\% more likely to be shared for each year he or she has been affiliated to their primary organization. Additionally, independent specialists are $10 \%$ less likely to be shared than specialists who are employed by their primary organization. Lastly, the likelihood of a specialist to be shared differs across medical specialties. In 21 of the 28 specialties the likelihood to be shared differs significantly from the reference category (see Appendix 2).

At the organizational level, neither the size of a specialist's primary organization nor the degree of competition to which it exposed significantly influence the likelihood of specialists to be shared. The type of organization to which a specialist is primarily affiliated and whether that organization is part of a MHS do significantly influence a specialist's likelihood to be shared. Specialists who are primarily affiliated to an academic hospital are $76 \%$ less likely to be shared than specialists affiliated to a general hospital (i.e. the reference category). Specialists affiliated to organizations which are part of a larger system of multiple organizations are $84 \%$ more likely to be shared.

\subsection{Likelihood of coopetition}

Model 2 in Table 4 presents the results of the regression model predicting the likelihood that a shared specialist is shared within a same strategic group (i.e. the likelihood of coopetition). At the individual level, the contract type, specialty of a medical specialist, and the traveling time between the primary and secondary organization all significantly influence a specialist's likelihood to be shared within a strategic group. Independent specialists are $31 \%$ less likely to be shared within a strategic group. A specialist is furthermore more likely to be shared within a strategic group if the organization to which he or she is shared is located further away, as indicated by the positive and significant effect of traveling time. However, the negative and significant effect of the squared travel time indicates that this likelihood decreases when the travel time between both organizations exceeds $96 \mathrm{~min}$. The likelihood of a specialist to be shared within a strategic group differs significantly from the reference category in 8 of the 28 medical specialties (see 
Table 4

Results of logistic multilevel regression predicting the likelihood that a specialist is shared (model 1) and shared to a competitor (model 2).

\begin{tabular}{|c|c|c|c|c|}
\hline & Model 1 & Odds Ratio Model 1 (95\% CI) & Model 2 & Odds Ratio Model 2 (95\% CI) \\
\hline \multicolumn{5}{|l|}{ Level-1 fixed effects } \\
\hline Intercept & $-2.017(0.246)^{* * *}$ & - & $-0.576(0.373)$ & - \\
\hline Gender & $0.220(0.048)^{* * *}$ & $1.246(1.135-1.369)$ & $0.103(0.094)$ & $1.108(0.921-1.334)$ \\
\hline $\mathrm{PhD}$ & $0.040(0.055)$ & $1.041(0.934-1.160)$ & $-0.038(0.108)$ & $0.963(0.779-1.190)$ \\
\hline Experience of specialist & $-0.001(0.005)$ & $0.999(0.989-1.008)$ & $0.005(0.010)$ & $1.005(0.986-1.024)$ \\
\hline Affiliation duration & $0.030(0.006)^{* * *}$ & $1.030(1.019-1.041)$ & $-0.011(0.011)$ & $0.989(0.968-1.010)$ \\
\hline Independent & $-0.110(0.054)^{* *}$ & $0.896(0.806-0.996)$ & $-0.372(0.103)^{* * *}$ & $0.689(0.563-0.844)$ \\
\hline Medical specialty & Omitted & See Appendix 2 & Omitted & See Appendix 2 \\
\hline Travel time & & & $1.230(0.279)^{* * *}$ & $3.420(1.978-5.914)$ \\
\hline Squared travel time & & & $-0.383(0.119)^{* * *}$ & $0.682(0.540-0.860)$ \\
\hline \multicolumn{5}{|l|}{ Level-2 fixed effects } \\
\hline Size & $0.129(0.109)$ & $1.138(0.920-1.408)$ & $-0.196(0.140)$ & $0.822(0.625-1.082)$ \\
\hline Competition & $0.011(0.011)$ & $1.012(0.989-1.034)$ & $-0.002(0.016)$ & $0.998(0.967-1.030)$ \\
\hline MHS membership & $0.612(0.189)^{* * *}$ & $1.845(1.274-2.671)$ & $-0.112(0.264)$ & $0.894(0.534-1.499)$ \\
\hline ITC & $0.387(0.253)$ & $1.473(0.897-2.420)$ & $0.890(0.349)^{* *}$ & $2.436(1.229-4.826)$ \\
\hline General hospital & Reference & - & Reference & - \\
\hline Teaching hospital & $-0.375(0.280)$ & $0.687(0.397-1.188)$ & $-0.346(0.372)$ & $0.707(0.341-1.467)$ \\
\hline Academic hospital & $-1.439(0.546)^{* * *}$ & $0.237(0.081-0.692)$ & $-0.753(0.725)$ & $0.471(0.114-1.950)$ \\
\hline \multicolumn{5}{|l|}{ Random effects } \\
\hline Level 2 intercept & $1.074(0.176)^{* * *}$ & & $1.784(0.334)^{* * *}$ & \\
\hline ICC & 0.246 & & 0.352 & \\
\hline \multicolumn{5}{|l|}{ Model fit } \\
\hline AIC & 14808.21 & & 4178.86 & \\
\hline ROC & 0.786 & & 0.843 & \\
\hline
\end{tabular}

Estimation method: Laplace.

* p-value $<0.10$.

** $\mathrm{p}$-value $<0.05$.

*** $\mathrm{p}$-value $<0.01$.

\section{Appendix 2).}

At the organizational level, neither the size, the degree of competition to which an organization is exposed, nor MHS membership influence the likelihood that a specialist is shared within a strategic group. The type of organization to which a specialist is primarily affiliated does have a significant influence on the likelihood of a specialist to be shared in a strategic group. Specialists who are primarily affiliated to an ITC are 2.44 times as likely to be shared to an organization in the same strategic group (i.e. another ITC) than specialists affiliated to a general hospital (i.e. the reference category).

\section{Discussion}

The aim of the study was to identify the individual and organizational determinants of cooperation and coopetition in health care. We based our analysis on shared human resources between healthcare organizations and used a multilevel approach to study which healthcare organizations share which human resources in general and to competitors. We find that more than a quarter of all specialists are shared. This contradicts the notion that specialists have a lifetime affiliation with one single hospital (Varkevisser et al., 2008). In line with previous research (Gee, 2000; Varkevisser et al., 2013; Westra et al., 2016) it instead indicates that sharing specialists is a common inter-organizational relation in health care. This is particularly true for male specialists which can be explained by the fact that females are three times more likely to work part-time than males in the Netherlands (CBS, 2015) and sharing part-time employees could erode the already limited availability of these employees to an organization.

Our results indicate that cooperation and coopetition entail different strategies. This becomes apparent in several ways. Firstly, the organizational level explains a considerable amount of the variance in a specialist's likelihood to be shared (to a competitor), underlining the notion that sharing medical specialists is a deliberate organizational strategy. Secondly, not all organizations which cooperate engage in coopetition. Sixty-one percent of the organizations in our study cooperate. Of those, $78 \%$ engage in coopetition. Thirdly, the type of specialists shared in general and shared to competitors differs. While male specialists and specialists with longer affiliations, and consequently higher degrees of firm-specific knowledge, are more likely to be shared in general, they are not more likely to be shared to competitors. There are furthermore significant differences between the likelihood to be shared versus the likelihood to be shared to competitors in several medical specialties. Lastly, coopetition is more common for ITCs while cooperation is more common for organizations which belong to a multihospital system but less common for academic hospitals. Coopetition ultimately entices decisions 'what to share, with whom, when, and under which conditions' (Levy et al., 2003, p. 4) and our results show that different organizations share different resources (i.e. specialists) in situations of cooperation versus coopetition.

Cooperation predominantly manifests itself through spin-off formation by general and teaching hospitals. Model 2 indicates that specialists shared to organizations in the same geographical market are likely to be shared to non-competitors. Subsequently, inspection of Table 3 reveals that 40\% (i.e. 1193 of 2952) of the specialists who are shared to non-competitors are shared to an ITC. Although such ambulatory clinics compete with hospitals for patients (Casalino et al., 2008), hospital boards do share specialists to ITCs which constitute (potential) competitors (Westra et al., 2016) and these ITCS are thus likely to constitute spin-offs. Creating a spin-off in the same geographical market furthermore minimizes the travel-time for specialists and allows hospitals to outsource 
certain activities while ensuring incoming referrals of patients (Westra et al., 2016). The finding that specialists with high degrees of firm-specific knowledge (i.e. longer affiliations to their primary organization) are more likely to be shared underlines the notion of spin-off formation as these specialists can maximize the alignment between both organizations.

Coopetition manifests itself most clearly in organizations which are active in the price competitive segment of the market. That is, ITCs typically perform services in the price competitive market segment (Nza, 2012) and specialists primarily affiliated to an ITC are 2.5 times more likely to be shared to a competitor. Furthermore, $45 \%$ of all specialists primarily affiliated to an ITC are shared. However, Model 2 also indicates that cooperation with competitors predominantly occurs with competitors located further (i.e. one hour on average) away. Given the local nature of specialized care markets (Sohn, 2002) these competitors thus reside in different geographical markets. The risk of anti-competitive effects resulting from sharing medical specialists suggested by previous research (Enthoven, 1988; Varkevisser et al., 2013; Westra et al., 2016) thus seem limited. The fact that coopetition seems most common in organizations which operate in the price-competitive market segment does raise the question on which criteria these organizations select appropriate partners to share their resources to. Future research should attempt to unravel these mechanisms at a dyadic level, preferably through longitudinal approaches.

Lastly, our results suggest that both cooperation and coopetition based on shared medical specialists fails to fulfill its full knowledgesharing potential. Inter-organizational learning and knowledge exchange are considered important drivers of coopetition in general and sharing specialists in particular (Bengtsson and Kock, 2014; Varkevisser et al., 2013; Westra et al., 2016) However, neither more experienced specialists nor specialists with medical seniority (i.e. those who have obtained a $\mathrm{PhD}$ ) are more likely to be shared. Healthcare providers thus seem reluctant to share their most experienced, specialized, and arguably most knowledgeable human resources. Furthermore, specialists who are primarily affiliated to an academic hospital and who typically have experience with treating the most complex patients are significantly less likely to be shared. Considered in conjunction with the finding that specialists with higher degrees of firm-specific knowledge are less likely to be shared, this result suggests that healthcare organizations seek to protect their competitive advantage (i.e. their most specialized resources).

\section{Limitations}

Our work is subject to a few caveats. Firstly, medical specialists and healthcare organizations are not obliged to possess an AGBcode. However, it is a requirement for reimbursement by health insurers. This constitutes a strong financial incentive to keep the database up to date, making it a reliable source for research purposes (Smeets et al., 2011). Additionally, the AGB-code database has recently undergone a quality review in which all specialists were requested to update their records (Vektis, 2016). Secondly, we have operationalized competitors through mutual strategic group membership. However, competition is not exclusive to organizations within a strategic group. Hospitals can cross-subsidize unprofitable services with the revenues of simpler services for which they compete with ITCs for example (Gaynor and Town, 2012). Nonetheless, organizations offer services which most closely resemble those offered by organizations from the same strategic group and the sub-industry categorization on which we based our strategic groups is generally accepted in multiple healthcare settings (Zwanziger et al., 1994).

\section{Conclusion}

The presence of price-competition in several healthcare markets makes it compelling to understand the mechanisms of cooperation and coopetition in the sector. In this paper we studied cooperation and coopetition between healthcare organizations based on shared human resources. We show that coopetition and cooperation entail different strategies in health care. That is, different organizations share different resources under circumstances of cooperation and competition. Cooperation predominantly manifests through spinoff formation. Coopetition occurs most in the price-competitive segment of the market but does not seem to be anti-competitive. However, healthcare organizations are reluctant to share their most specialized human resources, seemingly protecting their competitive advantage which limits the full knowledge-sharing potential of this type of inter-organizational relationship. Whether coopetition in healthcare benefits patients hence remains a point for future research.

\section{Acknowledgements}

The authors are grateful to the anonymous reviewers and the attendees of the Health Care Management division of the 2016 Academy of Management Annual Meeting in Anaheim (CA), USA for their valuable feedback. Furthermore the authors would like to acknowledge Huub Hoofs' appraisal of the analysis techniques.

\section{Appendix 1. Descriptive statistics of medical specialty dummies}

\begin{tabular}{|c|c|c|c|c|c|c|}
\hline & \multicolumn{3}{|c|}{$\begin{array}{l}\text { Model } 1 \\
(\mathrm{n}=15,431)\end{array}$} & \multicolumn{3}{|c|}{$\begin{array}{l}\text { Model } 2 \\
(n=4277)\end{array}$} \\
\hline & Mean & Min & Max & Mean & Min & $\operatorname{Max}$ \\
\hline Ophthalmology & $3.81 \%$ & 0 & 1 & $6.08 \%$ & 0 & 1 \\
\hline Ear nose throat & $3.05 \%$ & 0 & 1 & $2.81 \%$ & 0 & 1 \\
\hline Surgery & $7.42 \%$ & 0 & 1 & $8.44 \%$ & 0 & 1 \\
\hline Plastic surgery & $1.66 \%$ & 0 & 1 & $3.39 \%$ & 0 & 1 \\
\hline Orthopedics & $4.21 \%$ & 0 & 1 & $3.41 \%$ & 0 & 1 \\
\hline Urology & $2.43 \%$ & 0 & 1 & $3.06 \%$ & 0 & 1 \\
\hline Gynecology & $6.17 \%$ & 0 & 1 & $6.13 \%$ & 0 & 1 \\
\hline Neurosurgery & $0.86 \%$ & 0 & 1 & $2.10 \%$ & 0 & 1 \\
\hline Dermatology & $3.15 \%$ & 0 & 1 & $8.42 \%$ & 0 & 1 \\
\hline Pediatrics & $8.09 \%$ & 0 & 1 & $5.78 \%$ & 0 & 1 \\
\hline Gastroenterology & $2.82 \%$ & 0 & 1 & $2.57 \%$ & 0 & 1 \\
\hline Cardiology & $6.07 \%$ & 0 & 1 & $10.12 \%$ & 0 & 1 \\
\hline Pulmonology & $3.43 \%$ & 0 & 1 & $3.37 \%$ & 0 & 1 \\
\hline Rheumatology & $1.61 \%$ & 0 & 1 & $1.61 \%$ & 0 & 1 \\
\hline Allergology & $0.12 \%$ & 0 & 1 & $0.12 \%$ & 0 & 1 \\
\hline Rehabilitation & $1.72 \%$ & 0 & 1 & $1.31 \%$ & 0 & 1 \\
\hline Cardio thorax surgery & $0.73 \%$ & 0 & 1 & $0.33 \%$ & 0 & 1 \\
\hline Psychiatry & $3.27 \%$ & 0 & 1 & $1.75 \%$ & 0 & 1 \\
\hline Neurology & $5.02 \%$ & 0 & 1 & $3.02 \%$ & 0 & 1 \\
\hline Geriatrics & $1.50 \%$ & 0 & 1 & $1.26 \%$ & 0 & 1 \\
\hline Radiology & $5.97 \%$ & 0 & 1 & $5.59 \%$ & 0 & 1 \\
\hline Radiotherapy & $1.13 \%$ & 0 & 1 & $0.37 \%$ & 0 & 1 \\
\hline Nuclear medicine & $0.87 \%$ & 0 & 1 & $0.87 \%$ & 0 & 1 \\
\hline Clinical chemistry & $0.99 \%$ & 0 & 1 & $0.58 \%$ & 0 & 1 \\
\hline Microbiology & $0.97 \%$ & 0 & 1 & $1.08 \%$ & 0 & 1 \\
\hline Pathology & $1.76 \%$ & 0 & 1 & $1.64 \%$ & 0 & 1 \\
\hline Anesthesiology & $9.16 \%$ & 0 & 1 & $6.83 \%$ & 0 & 1 \\
\hline Clinical genetics & $0.63 \%$ & 0 & 1 & $0.12 \%$ & 0 & 1 \\
\hline Internal medicine & $11.38 \%$ & 0 & 1 & $7.86 \%$ & 0 & 1 \\
\hline
\end{tabular}




\section{Appendix 2. Odds ratios of medical specialty dummies omitted from Table 4}

\begin{tabular}{lll}
\hline & OR $(95 \%$ CI $)$ Model 1 & OR $(95 \%$ CI $)$ Model 2 \\
\hline Ophthalmology & $3.852(3.058-4.852)$ & $0.811(0.521-1.262)$ \\
Ear nose throat & $1.440(1.104-1.880)$ & $1.118(0.643-1.943)$ \\
Surgery & $1.954(1.613-2.369)$ & $0.896(0.603-1.332)$ \\
Plastic surgery & $6.074(4.469-8.257)$ & $0.641(0.366-1.121)$ \\
Orthopedics & $1.106(0.864-1.415)$ & $1.551(0.941-2.559)$ \\
Urology & $2.448(1.869-3.205)$ & $1.014(0.601-1.711)$ \\
Gynecology & $1.659(1.350-2.039)$ & $0.829(0.535-1.284)$ \\
Neurosurgery & $11.813(7.787-17.92)$ & $0.844(0.438-1.625)$ \\
Dermatology & $15.813(12.152-20.577)$ & $0.372(0.242-0.572)$ \\
Pediatrics & $1.147(0.933-1.409)$ & $1.199(0.773-1.858)$ \\
Gastroenterology & $1.472(1.120-1.936)$ & $1.298(0.734-2.295)$ \\
Cardiology & $3.756(3.086-4.571)$ & $0.318(0.210-0.482)$ \\
Pulmonology & $1.524(1.186-1.960)$ & $0.537(0.310-0.931)$ \\
Rheumatology & $1.874(1.347-2.606)$ & $1.454(0.750-2.820)$ \\
Allergology & $1.100(0.343-3.533)$ & $1.122(0.064-19.702)$ \\
Rehabilitation & $1.213(0.851-1.730)$ & $0.581(0.270-1.251)$ \\
Cardio thorax surgery & $0.800(0.442-1.449)$ & $4.832(1.399-16.695)$ \\
Psychiatry & $0.532(0.381-0.743)$ & $0.803(0.397-1.622)$ \\
Neurology & $0.754(0.587-0.969)$ & $1.169(0.688-1.988)$ \\
Geriatrics & $1.489(1.034-2.145)$ & $2.142(1.061-4.324)$ \\
Radiology & $1.279(1.032-1.585)$ & $0.901(0.57-1.423)$ \\
Radiotherapy & $0.540(0.308-0.947)$ & $0.006(<0.001->999.999)$ \\
Nuclear medicine & $1.925(1.249-2.964)$ & $1.087(0.463-2.549)$ \\
Clinical chemistry & $0.633(0.385-1.040)$ & $0.908(0.318-2.592)$ \\
Microbiology & $1.923(1.271-2.909)$ & $1.389(0.629-3.066)$ \\
Pathology & $1.563(1.121-2.179)$ & $2.069(1.101-3.885)$ \\
Anesthesiology & $1.026(0.843-1.249)$ & $1.745(1.171-2.601)$ \\
Clinical genetics & $0.542(0.216-1.360)$ & $1.426(0.146-13.901)$ \\
Internal medicine & - & - \\
\hline & & \\
& & \\
& &
\end{tabular}

\section{References}

Barretta, A., 2008. The functioning of co-opetition in the health-care sector: an explorative analysis. Scand. J. Manag. 24 (3), 209-220.

Bengtsson, M., Kock, S., 2000. "Coopetition" in business Networks-to cooperate and compete simultaneously. Ind. Mark. Manag. 29 (5), 411-426.

Bengtsson, M., Kock, S., 2014. Coopetition-quo vadis? Past accomplishments and future challenges. Ind. Mark. Manag. 43 (2), 180-188.

Bouncken, R.B., Gast, J., Kraus, S., Bogers, M., 2015. Coopetition: a systematic review, synthesis, and future research directions. Rev. Manag. Sci. 9 (3), 577-601.

Brandenburger, A.M., Nalebuff, B.J., 1996. Co-opetition. Doubleday, USA.

Casalino, L.P., November, E.A., Berenson, R.A., Pham, H.H., 2008. Hospital-physician relations: two tracks and the decline of the voluntary medical staff model. Health Aff. 27 (5), 1305-1314.

CBS, 2015. Meer werkende vrouwen. Retrieved 09-01-2016, 2016, from. http:// www.cbs.nl/nl-nl/menu/themas/arbeid-sociale-zekerheid/publicaties/ artikelen/archief/2015/meer-werkende-vrouwen.htm.

Corredoira, R.A., Rosenkopf, L., 2010. Should auld acquaintance be forgot? The reverse transfer of knowledge through mobility ties. Strategic Manag. J. 31 (2), 159-181.

Cutler, D.M., 2002. Equality, efficiency, and market fundamentals: the dynamics of international medical-care reform. J. Econ. Literature 40 (3), 881-906.

Das, T.K., Teng, B.-S., 2000. Instabilities of strategic alliances: an internal tensions perspective. Organ. Sci. 11 (1), 77-101.

de Rouw, M., 2016. Beheer en Onderhoud Vernieuwde AGB-register. Versie 1.11. Vektis, Zeist, p. 176.

Dranove, D., Shanley, M., 1995. Cost reductions or reputation enhancement as motives for mergers: the logic of multihospital systems. Strategic Manag. J. 16, $55-74$.

Enthoven, A.C., 1988. Theory and Practice of Managed Competition in Health Care Finance. Elsevier Science Publishers B.V, Amsterdam, the Netherlands.

Enthoven, A.C., 1993. The history and principles of managed competition. Health Aff. 12 (Suppl. 1), 24-48.

Enthoven, A.C., van de Ven, W.P., 2007. Going Dutch-managed-competition health insurance in The Netherlands. N. Engl. J. Med. 357 (24), 2421-2423.

Fottler, M.D., Schermerhorn Jr., J.R., Wong, J., Money, W.H., 1982. Multi-Institutional arrangements in health care: review, analysis and a proposal for future research. Acad. Manag. Rev. 7 (1), 67-79.

Gaynor, M., Town, R.J., 2012. Competition in Health Care Markets. The Centre for
Market and Public Organisation, Bristol, United Kingdom.

Gee, E.P. 2000. Co-opetition: the new market milieu. J. Healthc. Manag. 45 (6), 359.

Gittell, J.H., Weiss, L., 2004. Coordination networks within and across organizations: a multi-level framework. J. Manag. Stud. 41 (1), 127-153.

Gnyawali, D.R., Park, B.-J.R., 2011. Co-opetition between giants: collaboration with competitors for technological innovation. Res. Policy 40 (5), 650-663.

Goes, J.B., Park, S.H., 1997. Interorganizational links and innovation: the case of hospital services. Acad. Manag. J. 40 (3), 673-696.

Ingram, P., Yue, L.Q., 2008. 6 structure, affect and identity as bases of organizational competition and cooperation. Acad. Manag. Ann. 2 (1), 275-303.

Jarillo, J.C., 1988. On strategic networks. Strategic Manag. J. 9 (1), 31-41.

Landon, B.E., Keating, N.L., Barnett, M.L., Onnela, J.-P., Paul, S., O'Malley, A.J., et al., 2012. Variation in patient-sharing networks of physicians across the United States. JAMA 308 (2), 265-273.

Lane, J., Parkin, M., 1998. Turnover in an accounting firm. J. Labor Econ. 16 (4) 702-717.

Levine, S., White, P.E., 1961. Exchange as conceptual framework for the study of interorganizational relationships. Adm. Sci. Q. 5 (4), 583-601.

Levy, M., Loebbecke, C., Powell, P., 2003. SMEs, co-opetition and knowledge sharing: the role of information systems. Eur. J. Inf. Syst. 12, 3-17.

Lomi, A., Mascia, D., Vu, D.Q., Pallotti, F., Conaldi, G., Iwashyna, T.J., 2014. Quality of care and interhospital collaboration: a study of patient transfers in Italy. Med. Care 52 (5), 407-414.

Lomi, A., Pallotti, F., 2012. Relational collaboration among spatial multipoint competitors. Soc. Netw. 34 (1), 101-111.

Luke, R.D., Begun, J.W., Pointer, D.D., 1989. Quasi firms: strategic interorganizational forms in the health care industry. Acad. Manag. Rev. 14 (1), 9-19.

Maarse, H., Jeurissen, P., Ruwaard, D., 2016. Results of the market-oriented reform in The Netherlands: a review. Health Econ. Policy Law 11 (02), 161-178.

Madsen, T.L., Mosakowski, E., Zaheer, S., 2003. Knowledge retention and personnel mobility: the nondisruptive effects of inflows of experience. Organ. Sci. 14 (2), 173-191.

Marlin, D., Huonker, J.W., Sun, M., 2002. An examination of the relationship between strategic group membership and hospital performance. Health Care Manag. Rev. 27 (4), 18-29.

Mascia, D., Di Vincenzo, F., 2011. Understanding hospital performance: the role of network ties and patterns of competition. Health Care Manag. Rev. 36 (4), 327-337.

Mascia, D., di Vincenzo, F., 2013. Dynamics of hospital competition: social network analysis in the Italian national health service. Health Care Manag. Rev. 38 (3) 234-247.

Mascia, D., Di Vincenzo, F., Cicchetti, A., 2012. Dynamic analysis of interhospital collaboration and competition: empiricial evidence from an Italian regional health system. Health Policy 105 (1), 273-281.

Mascia, D., Di Vincenzo, F., Iacopino, V., Fantini, M.P., Chicchetti, A., 2015. Unfolding similarity in interphysician networks: the impact of institutional and professional homophily. BMC health Serv. Res. 15 (92), 1-8.

Mascia, D., Pallotti, F., Angeli, F., 2016. Don't stand so close to me: competitive pressures, proximity and inter-organizational collaboration. Reg. Stud. 1-14.

McGee, J., Thomas, H., 1986. Strategic groups: theory, research and taxonomy Strategic Manag. J. 7 (2), 141-160.

Nza, 2012. Monitor zelfstandig behandelcentra. Een kwalitatieve en kwantitatieve analyse. Nederlandse zorg autoriteit, Utrecht, p. 36.

Nza, 2014. Marktscan en beleidsbrief Medisch Specialistische Zorg 2014: Weergave van de markt 2010-2014 Deel A. Nederlandse zorg autoriteit, Utrecht, the Netherlands.

Nza, 2015. Marktscan van de medisch specialistische zorg 2015. Dutch Healthcare Authority, Utrecht, the Netherlands.

Oliver, C., 1990. Determinants of interorganizational relationships: integration and future directions. Acad. Manag. Rev. 15 (2), 241-265.

Peng, T.J.A., Bourne, M., 2009. The coexistence of competition and cooperation between networks: implications from two Taiwanese healthcare networks. Br. J. Manag. 20 (3), 377-400.

Plochg, T., Delnoij, D.M., Hoogedoorn, N.P., Klazinga, N.S., 2006. Collaborating while competing? The sustainability of community-based integrated care initiatives through a health partnership. BMC Health Serv. Res. 6 (1), 37.

Porter, M., 2010. What is value in health care? N. Engl. J. Med. 363 (26), 2477-2481.

Provan, K.G., Beagles, J.E., Leischow, S.J., 2011. Network formation, governance, and evolution in public health: the North american quitline consortium case. Health Care Manag. Rev. 36 (4), 315-326.

Provan, K.G., Milward, H.B., 1995. A preliminary theory of network effectiveness: a comparative study of four community mental health systems. Adm. Sci. Q. 40 (1), 1-33.

Provan, K.G., Sebastian, J.G., 1998. Networks within networks: service link overlap, organizational cliques, and network effectiveness. Acad. Manag. J. 41 (4), 453-463.

Quint, B., 1997. Coopetition: sleeping with the enemy. Inf. Today 14 (1), 7-8.

Ritala, P., Hurmelinna-Laukkanen, P., 2009. What's in it for me? Creating and appropriating value in innovation-related coopetition. Technovation 29 (12), 819-828.

Robinson, J.C., Luft, H.S., 1985. The impact of hospital market structure on patient volume, average length of stay, and the cost of care. J. Health Econ. 4 (4), 333-356.

Scholten, G.R.M., Van der Grinten, T.E.D., 2005. The integration of medical specialists in hospitals. Dutch hospitals and medical specialists on the road to join 
regulation. Health Policy 72 (2), 165-173.

Schut, F.T., Varkevisser, M., 2017. Competition policy for health care provision in The Netherlands. Health Policy 121 (2), 126-133.

Smeets, H.M., de Wit, N.J., Hoes, A.W., 2011. Routine health insurance data for scientific research: potential and limitations of the agis health database. J. Clin. Epidemiol. 64 (4), 424-430.

Snijders, T.A., Bosker, R.J., 2012. Multilevel Analysis: an Introduction to Basic and Advanced Multilevel Modeling, n. edition. Sage Publishers, London, United Kingdom.

Sohn, M.W., 2002. A relational approach to measuring competition among hospitals. Health Serv. Res. 37 (2), 457-482.

Van de Ven, A.H., 1976. On the nature, formation, and maintenance of relations among organizations. Acad. Manag. Rev. 1 (4), 24-36.

van der Velden, L.F.J., Hingstman, L., 2003. Het medisch opleidingstraject: Waar blijft de (leef)tijd, vol. 81. Nivel, Utrecht, the Netherlands.

Varkevisser, M., Capps, C.S., Schut, F.T. 2008. Defining hospital markets for antitrust enforcement: new approaches and their applicability to The Netherlands. Health Econ. Policy Law 3 (01), 7-29.

Varkevisser, M., van der Geest, S.A., Loozen, E.M.H., Mosca, I., Schut, F.T., 2013.
Instellingsoverstijgende maatschappen: Huidige ontwikkelingen, mogelijke gevolgen en de aanpak van eventuele mededingingsproblemen. iBMG, Rotterdam.

Vektis, 2015. Zorgprisma Publiek: Hoe hoog zijn de totale zorgkosten in Nederland? Cognos, Zeist, the Netherlands.

Vektis, 2016. Kwaliteitsactie AGB-code. Retrieved 29-08-2016, 2016, from. https:// www.agbcode.nl/content/kwaliteitsactie.

Westra, D., Angeli, F., Carree, M., Ruwaard, D., 2017. Understanding competition between healthcare providers: introducing an intermediary interorganizational perspective. Health Policy 121 (2), 149-157.

Westra, D., Angeli, F., Jatautaitè, E., Carree, M., Ruwaard, D., 2016. Understanding specialist sharing: a mixed-method exploration in an increasingly pricecompetitive hospital market. Soc. Sci. Med. 162, 133-142.

Zuckerman, H.S., Kaluzny, A.D., Ricketts, T.C.I., 1995. Alliances in health care: what we know, what we think we know, and what we should know. Health Care Manag. Rev. 20 (1), 54-64.

Zwanziger, J., Melnick, G., Eyre, K.M., 1994. Hospitals and antitrust: defining markets, setting standards. J. Health Polit. Policy Law 19 (2), 423-447. 